\title{
Spiller kostholdet en rolle i utviklingen av type 1 diabetes?
}

\author{
Lars Christian Stene ${ }^{1,2}$ og Geir Joner ${ }^{1,2}$ \\ ${ }^{I}$ Aker diabetes forskningssenter, Aker Sykehus, 0514 Oslo \\ ${ }^{2}$ Seksjon for epidemiologi, Statens institutt for folkehelse, Postboks 4404 Torshov, 0403 Oslo \\ Korrespondanse: Lars Christian Stene, Seksjon for epidemiologi, Statens institutt for folkehelse, Postboks 4404 Torshov, 0403 Oslo \\ Telefon 22042399 telefaks $22042351 \quad$ e-post: lars.christian.stene@folkehelsa.no
}

\begin{abstract}
SAMMENDRAG
Målsetningen med denne artikkelen er å diskutere litteraturen om kosthold og risiko for utvikling av type 1 diabetes mellitus, med vekt på epidemiologiske studier. Vi vil også presentere litt om forskningsaktiviteten på dette området i Norge. Vi har et godt teoretisk grunnlag for å anta at kostholdsfaktorer kan være involvert i etiologien til type 1 diabetes, og en rekke studier har bidratt med holdepunkter for at en sammenheng eksisterer. Det er flest studier på amming og avvenningskost, men også andre spesifikke komponenter i kostholdet har vært implisert, for eksempel planteproteiner, nitrat i drikkevann og enkelte vitaminer. Det er foreløpig amming og kumelk som ser ut til å være de mest lovende faktorer med tanke på muligheten for å kunne forebygge type 1 diabetes, men det er etter vårt syn foreløpig ikke grunnlag for å gå ut med anbefalinger om kostholdsendringer.
\end{abstract}

Stene LC, Joner G. Does diet play a role in type 1 diabetes? Nor J Epidemiol 2000; 10 (1): 71-78.

\section{ENGLISH SUMMARY}

The aim of this article is to discuss the literature on diet and the risk of developing type 1 diabetes mellitus, with emphasis on epidemiologic studies. We will also briefly present some of the research activity in this field in Norway. We have a good theoretical foundation for assuming that dietary factors may play a role in the etiology of type 1 diabetes, and several studies have provided evidence that a relationship exists. Most of these studies are on infant feeding practices, but other specific factors, such as plant proteins, nitrate and vitamins have also been implicated. Breast-feeding and cow's milk are the most promising factors to date, but there is in our view still not sufficient evidence to recommend modification of feeding practices in order to prevent type 1 diabetes.

\section{INNLEDNING}

Type 1 diabetes mellitus er en av de vanligste kroniske og livslange sykdommer blant barn i den vestlige verden. Det er en sykdom hvor kroppens eget immunforsvar spesifikt angriper de insulinproduserende $\square$ cellene i pancreas (bukspyttkjertelen). Sykdomsprosessen kan vare fra noen måneder til flere år før klinisk sykdom oppstår (1), men årsaken til at denne prosessen starter er ukjent (2). Ved klinisk debut er som regel insulinproduksjonen redusert til $10-20 \%$ av det normale. Insidensraten øker med alder til en topp omkring puberteten, dvs. ved alder 12 år for jenter og 14 år for gutter $(3,4)$. Type 1 diabetes debuterer som regel i relativt ung alder, vanligvis før 30 -års alderen, men kan debutere i alle aldre (5). Insidensraten blant barn under 15 år varierer kraftig mellom land, fra under 2/100 000 personår i flere land i Asia til mer enn 35/100 000 personår i Finland (6). I Norge var insidensen i gjennomsnitt 20,5/100 000 personår i perioden 1973-1982, med en signifikant øking fra 18,5 til 22,7 fra første til andre femårsperiode (3). Fra 1989 til 1998 har insidensen vært 22,5 per 100000 personår, og stabil i hele perioden (Joner et al., upublisert observasjon). Sannsynligheten for å utvikle type 1 diabetes før 15 års alder i den generelle befolkningen er gjennomsnittlig ca. 0,3-0,4\%.

Det er enighet om at både genetisk disposisjon og miljøfaktorer spiller en rolle i utviklingen av type 1 diabetes (1). Gener i HLA-systemet er assosiert med risiko for type 1 diabetes $(7,8)$. Også gener utenfor HLA-systemet er involvert, men det er sannsynligvis ingen enkeltgener utenfor HLA-systemet som har stor betydning alene (8). Tvillingstudier indikerer at blant par av eneggede tvillinger der minst én har type 1 diabetes, vil begge tvillingene ha sykdommen i ca. 30$50 \%$ av parene, selv etter mange års oppfølging $(9,10)$. Dette tyder på at gener alene ikke er tilstrekkelig for å 
utvikle type 1 diabetes. Den økningen man har observert i insidens i mange land (11) kan ikke forklares av genetiske forhold alene. Det er vanlig å anta at gener regulerer mottageligheten for sykdom og at predisponerte personer kan reagere på stimuli fra miljøfaktorer som virus, kjemikalier eller kosthold som kan føre til $ø$ deleggelse av de insulinproduserende $\square$-cellene ved autoimmune mekanismer og/eller manglende regenerering av $\mathrm{Z}$-celler (12). Hvis man kan påvise at miljøfaktorer spiller en rolle i utviklingen av type 1 diabetes kan denne kunnskapen potensielt brukes i forebyggende tiltak i fremtiden.

I 1984 fremsatte Borch-Johnsen og medarbeidere hypotesen om at amming beskytter mot type 1 diabetes hos barn (13), basert på data fra Skandinavia. Samme år fant Elliott og Martin at inntak av proteiner fra enten melk eller hvete økte insidensen av diabetes hos rotter sammenlignet med en diett hvor proteinene var erstattet med frie aminosyrer (14). Siden har forskningen på sammenhengen mellom ernæringsfaktorer og type 1 diabetes vært et aktivt felt. På bakgrunn av data fra case-control studier, immunologiske studier og dyrestudier gikk American Academy of Pediatrics i 1994 ut med anbefalinger for familier med type 1 diabetes om at spedbarn bør unngå kumelkprodukter i første leveår (15). Arbeidsgruppen kom med denne anbefalingen på tross av at de også konkluderete med at sammenheng mellom tidlig introduksjon av kumelk og senere utvikling av type 1 diabetes krever bekreftelse fra flere studier. De anbefalte også at soya-baserte morsmelkerstatninger skulle unngås. Anbefalingene utløste en rekke reaksjoner fra fremstående forskere på feltet som mente at det ikke var tilstrekkelig med holdepunkter for å gå ut med slike anbefalinger (16-19). I denne artikkelen vil vi diskutere om kostholdet kan spille en rolle i utviklingen av type 1 diabetes hos barn. Vi går gjennom den sentrale litteraturen på området med vekt på epidemiologiske studier, samt presenterer litt om forskningsaktiviteten på dette området i Norge.

\section{AMMING OG KUMELK}

Økologiske studier mellom land og innen land har vist at det er en sterk sterk lineær sammenheng mellom insidensen av type 1 diabetes hos barn og totalt melkeforbruk (20-22). En rekke case-control studier av amming og tidlig introduksjon av kumelk i utviklingen av type 1 diabetes er publisert. I en oversiktsartikkel fra 1998 summerte Åkerblom og Knip 22 publiserte studier (23). De fleste studiene viste en positiv assosiasjon mellom kortvarig amming eller tidlig introduksjon av kumelk og risiko for type 1 diabetes, men i en del studier har man ikke funnet signifikant sammenheng (i tre studier har man funnet svak negativ assosiasjon). Norris og Scott påpekte at det var heterogenitet mellom studier både med hensyn på metodologi og resultater (24). De forsøkte gjennom en meta-analyse av 20 studier å identifisere faktorer som kunne forklare heterogeniteten i resultater. Meta-analysen indikerte at introduksjon av kumelk før 3 måneders alder var forbundet med en odds ratio på 1,6 for utvikling av type 1 diabetes og at eksklusiv amming mindre enn 3 måneder var forbundet med en odds ratio på $1,4 \mathrm{i}$ forhold til eksklusiv amming 3 måneder eller mer. Disse forfatterne mente at denne relativt svake assosiasjonen kunne skyldes metodiske svakheter, spesielt rapporteringsfeil (recall bias). Dette var først og fremst basert på at det i de 3 studiene som brukte eksisterende journaler med informasjon om eksponering registrert før sykdomsutvikling (25-27) ikke ble påvist noen klar assosiasjon. Få har tydeligvis kommentert at hvis assosiasjonen er svak (odds ratio ca. 1,5), så kreves relativt store studier for å påvise signifikant sammenheng, og man må forvente tilfeldig variasjon i resultatene mellom studier. Man kan allikevel ikke utelukke at en så svak assosiasjon kan skyldes recall bias eller confounding.

I enkelte studier har man studert sammenhengen mellom amming eller tidspunkt for introduksjon av kumelk og utvikling av såkalt prediabetes, eller D-celle autoimmunitet. Disse har ikke påvist signifikant sammenheng $(28,29)$. Prediabetes er oftest definert som tilstedeværelse av en eller flere diabetesassosierte autoantistoffer (antistoffer mot insulin (IAA), øyceller (ICA), glutaminsyre dekarboksylase (GAD) og protein tyrosin fosfatase-2 (IA-2)). Avhengig av definisjonen vil inntil $70-80 \%$ av barn som har prediabetes utvikle type 1 diabetes innen 5-10 år (30). Disse studiene av amming/kumelk og prediabetes har svært lav statistisk styrke, siden få individer hadde utviklet autoantistoffer $(30,31)$. På tross av at enkelte har tatt disse studiene til inntekt for å demonstrere at det ikke er noen sammenheng mellom kortvarig amming eller tidlig introduksjon av kumelk og utvikling av prediabetes, mener vi at dataene ikke tillater en slik konklusjon. I tillegg, for å kunne ekstrapolere slike resultater til å gjelde type 1 diabetes må man anta at alle med prediabetes vil utvikle diabetes, noe som neppe er tilfelle. Estimert positiv prediktiv verdi (uavhengig av eksponering) for definisjonen av prediabetes som ble brukt $i$ en studie var under $50 \%(28,31)$. Videre, siden den positive prediktive verdi er under $100 \%$, må man strengt tatt anta at den er lik for de eksponerte og de ikke-eksponerte. Data om dette eksisterer så vidt vi vet ikke.

\section{Mulige mekanismer}

Morsmelk inneholder vekstfaktorer, cytokiner og andre stoffer som fremmer modningen av tarmen hos spedbarn. Morsmelk inneholder også antistoffer som kan overføres til diende spedbarn og beskytte mot mage/tarminfeksjoner (32). Disse faktorene kan tenkes å hindre absorbsjon av intakte antigener som kan øke risikoen for diabetes og/eller beskytte mot infeksjoner som kan øke risikoen for diabetes. På en annen side har mye fokus har vært rettet mot immunologiske reaksjoner mot spesifikke komponenter i kumelk. Det er påvist økte nivåer av antistoff mot kumelkproteiner, 
blant annet mot beta-laktoglobulin, i blodet til nydiagnostiserte unge type 1 diabetes pasienter $(33,34)$. Karjalainen et al. (35) rapporterte i 1992 at nær 100\% av nydiagnostiserte unge type 1 diabetikere hadde antistoffer mot bovint serum albumin (BSA). De hevdet at en aminosyresekvens i BSA-proteinet var lik den $\mathrm{i}$ et protein som kan uttrykkes på $\square$-celler, og at dette kunne utløse en immunologisk kryssreaksjon. Introduksjon av kumelk i perioden mens barns tarm er umoden og kan absorbere intakte deler av BSA proteinet ville under denne hypotesen kunne utløse en immunreaksjon som fører til spesifikt angrep på $\square$ cellene. Den såkalte BSA hypotesen er meget sofistikert, men er basert på en del antakelser som det foreløpig ikke finnes støtte for (36). Flere grupper har forsøkt å reprodusere funnet til Karja lainen et al., men konklusjonene har vært at det kan ha vært artefakt $(37,38)$. Det kan imidlertid ikke utelukkes at andre mekansimer er involvert.

I den senere tid har enkelte grupper dreid oppmerksomheten mot et annet protein i kumelk, nemlig $\square$-kasein. I en studie ble det påvist økte nivåer av antistoffer mot $\square$-kasein blant nydiagnostiserte diabetikere, men ikke hos friske kontroller eller personer med autoimmun tyreoiditt (39). Det finnes mange varianter av $\square$-kasein, avhengig av melkekuenes gener, og i følge Elliott et al. skal visse typer være forbundet med potensielle biologiske effekter som de spekulerer kan øke risikoen for type 1 diabetes (40). De fant støtte for sin hypotese i en økologisk analyse der de sammenlignet estimert forbruk av visse $\square$-kasein varianter og insidensen av type 1 diabetes hos barn. Økologiske studier er ikke tilstrekkelig grunnlag til å trekke noen konklusjoner, men sammenholdt med enkelte eksperimentelle data gir det grunnlag for å fortsette forskningen på dette feltet.

Kumelk inneholder bovint insulin, som er forskjellig fra humant insulin $\mathrm{i}$ bare tre aminosyrer. En finsk gruppe viste at barn som hadde fått kumelkbasert morsmelkerstatning (som inneholdt bovint insulin) hadde økte nivåer av IgG antistoffer mot bovint insulin ved 6 måneders alder sammenlignet med barn som hadde fått hydrolysert morsmelkerstatning eller som var eksklusivt ammet $(41,42)$. Disse antistoffene kryssreagerte med humant insulin, noe som støtter hypotesen om at bovint insulin kan utløse en autoimmun reaksjon mot de insulinproduserende cellene $i$ pancreas. Det var imidlertid ikke forskjell i antistoffnivå etter 9 måneder, da alle barna fikk kumelk, og heller ikke korrelasjon mellom alder ved introduksjon av kumelk og antistoffnivå (41). Økte nivåer av antistoffer mot kumelkproteiner eller insulin kan være uttrykk for en generelt økt immunologisk sensitivitet hos individer som utvikler type 1 diabetes eller andre autoimmune sykdommer, muligens pga. genetiske forhold. Det kan tenkes at immunologiske reaksjoner mot kumelk oppstår fordi det som oftest er det første tarmmukosaen hos spedbarn blir eksponert for, eventuelt etter morsmelk (43). Man kan alstå tenke seg flere plausible mekanismer både for en beskyttende effekt av morsmelk og en risikoøkende effekt ved tidlig introduksjon av kumelk, men det er vanskelig å identifisere den eller de mekanismer som eventuelt virker hos mennesker.

\section{Pågående randomisert kontrollert studie}

En finsk forskergruppe har startet en randomisert pilotstudie for å undersøke om unngåelse av kumelk i de første 6-9 levemåneder kan forebygge eller forsinke utvikling av type 1 diabetes hos barn med økt genetisk risiko (44). Barn som har foreldre eller søsken med type 1 diabetes og som i tillegg har HLA-gener som predisponerer for type 1 diabetes følges fra fødsel. Alle mødre oppfordres til å amme, samt å unngå kumelk og storfekjøtt i ammeperioden. Barna randomiseres til en av to grupper. Når de skal begynne å bruke morsmelkerstatning får en gruppe hydrolysert morsmelkerstatning (Nutramigen), mens den andre gruppen får vanlig kumelkbasert morsmelkerstatning. Foreløpige resultater fra denne pilotstudien med ca. 160 barn tyder på at fravær av intakte kumelkproteiner de første 6-9 måneder av livet kan ha en beskyttende effekt med hensyn på prediabetes. Per november 1999 hadde kun fem personer utviklet type 1 diabetes, to i intervensjonsgruppen og tre i kontrollgruppen (Åkerblom et al., Modulation of the appearance of diabetes associated autoantibodies in the nutritional prevention of type 1 diabetes (TRIGR) project. Presentert på 4th Immunology of Diabetes Society Congress, Fiuggi, Italia 12.-15. november, 1999). Dette er for få til å kunne si noe om effekten på diabetes. De endelige resultatene fra denne pilotstudien ventes å foreligge $\mathrm{i}$ år 2000. Flere spørsmål vil imidlertid forbli ubesvart etter dette. For å besvare spørsmålet om intervensjonen virkelig forebygger diabetes hos personer med økt genetisk risiko eller om man bare utsetter klinisk debut kreves lang oppfølging av deltakerne. Deres åpne design og mange interimanalyser vil sannsynligvis føre til invendinger mot signifikansen av eventuelle funn. Pilotstudien vil sannsynligvis gi svar på spørsmålet om det er grunnlag for å sette i gang en hovedstudie.

\section{ANDRE FAKTORER}

\section{Gluten, soya og planteproteiner}

Det er vist økning av antistoffer mot gliadin blant personer med type 1 diabetes (45), og det er overhyppighet av cøliaki blant personer med type 1 diabetes $(46,47)$. Genetiske forhold indikerer at det kan være likhetstrekk i patogenesen til cøliaki og type 1 diabetes (48-50). Proteiner fra hvete og fra soya har vist seg å øte insidensen av diabetes i dyremodeller $(14,51,52)$. Det at tidlig introduksjon av fast føde er assosiert med utvikling av type 1 diabetes i enkelte case-control studier (53) gir indirekte støtte for en slik sammenheng, siden mange spedbarn tidlig får grøt basert på hvete. Funn som direkte støtter hypotesen om at tidlig intro- 
duksjon av hvete eller soya kan være assosiert med type 1 diabetes er gjort i kun én case-control studie (54), og denne har flere metodiske svakheter (16). I en studie fra Finland fant man økt cellulær immunrespons mot hvete-gluten blant ca. $25 \%$ av personer som nylig hadde blitt diagnostisert med type 1 diabetes, mens blant kontroller hadde ca. 5\% økt T-celle reaktivitet overfor hvete-gluten (55). Det kan ikke utelukkes at dette skyldes en generelt økt immunrespons hos individer med diabetes.

\section{Nitrat og nitritt}

Da Helgason \& Jonasson observerte at det på Island var en signifikant økning i insidens blant gutter født i oktober spekulerte de på at dette kunne skyldes foreldrenes intak av røyket lam ved juletider, dvs. omkring befruktningen (56). Røyket lam inneholder nitrat og nitritt som kan omdannes til N-nitrosoforbindelser, en gruppe stoffer som strukturelt ligner på streptozotocin som fører til diabetes i forsøksdyr (57). Senere ble det vist at inntak av røyket lam omkring befruktningen $ø$ kte diabetes-insidensen hos avkommet hos mus (58). Denne historien har i ettertid ikke utviklet seg særlig, med noen få unntak. Drikkevann kan være en viktig kilde til inntak av nitrat, og en svak sammenhengen mellom konsentrasjonen av nitrat i drikkevannskilder og insidensen av type 1 diabetes hos barn i forskjellige områder innen enkeltland er funnet i noen økologiske studier $(59,60)$. I andre land, inkludert Norge har man imidlertid ikke kunnet påvise en slik sammenheng (61), (Geir Joner \& Øystein Krüger, upubliserte resultater). Det er meget vanskelig å måle inntak av nitrat, nitritt eller N-nitrosoforbindelser, men sammenhengen mellom disse stoffene og type 1 diabetes er forsøkt belyst i enkelte case-control studier med varierende resultater (62-65). Virtanen et al. fant i en populasjonsbasert studie i Finland en signifikant sammenheng mellom inntak av nitritt (men ikke nitrat) blant barn og deres mødre, og risiko for type 1 diabetes (65).

\section{Vitamin D}

Det har blitt vist i eksperimentelle studier at vitamin D (1,25-dihydroxyvitamin $\mathrm{D}_{3}$ ) kan modifisere immunfunksjon og forebygge diabetes i dyremodeller (66). På bakgrunn av dette ble det gjort en multisenter casecontrol studie i Europa hvor eksponeringen var bruk av vitamin D supplement i første leveår (67). På tross av noe variasjon over sentra ble det påvist en negativ assosiasjon med type 1 diabetes, og en sammenslått odds ratio på 0,67 for de som hadde fått vitamin $\mathrm{D}$ versus de som ikke hadde fått det. Disse resultatene krever bekreftelse fra flere studier.

\section{Sukker?}

Himsworth skrev i 1935: "It is only natural that excessive consumption of sugar should sooner or later be suggested as a factor in the causation of diabetes mellitus. The work of Joslin, Kulin and Marks \& Mills has, however, shown that there is no evidence in support of this suggestion" (68). Dette gjaldt først og fremst type 2 diabetes. Når det gjelder type 1 finnes lite data, og det er idag ingen grunn til å tro at inntak av sukker øker risikoen for type 1 diabets. Da Pozzilli \& Bottazzo rapporterte at de hadde funnet en økologisk sammenheng mellom nasjonalt sukkerforbruk og insidensen av type 1 diabetes i forskjellige land, var det først og fremst ment som en kritikk av økologiske studier (69). I en populasjonsbasert case-control studie fra Sverige fant man ingen sammenheng mellom inntak av mono- eller disakkarider og risiko for type 1 diabetes hos barn (63).

\section{Intervensjonsstudie: nikotinamid}

Store doser av B-vitaminet nikotinamid (niacinamid) har vist seg å kunne forebygge diabetes i dyremodeller, og foreløpige resultater fra en pilotstudie (70) gir indikasjoner for at høye doser kan forebygge eller utsette utvikling av type 1 diabetes hos barn med meget høy risiko for å utvikle diabetes (langt fremskredet prediabetes). Nikotinamid inngår i koenzymene nikotinamid adenin dinukleotid (NAD) og NAD fosfat (NADPH). Mer enn 200 enzymer er avhengige av NAD og NADPH, de fleste er involvert i energiomsetningen (71). Anbefalt daglig inntak av niacin (inkludert fra nikotinsyre og tryptofan) er omtrent 15-20 $\mathrm{mg}$, avhengig av energiinntak, og dette dekkes av et normalt vestlig kosthold (72). Norge er for tiden med i en multisenter randomisert studie for å undersøke om nikotinamid kan forebygge utvikling av type 1 diabetes hos barn eller søsken av personer med type 1 diabetes, European Nikotinamid Diabetes Intervention Trial (ENDIT). Førstegradsslektninger til personer med type 1 diabetes screenes for tilstedeværelse av diabetesassosierte autoantistoffer. Antistoff-positive slektninger randomiseres til å motta enten placebo eller en oral dose på 1000-2000 mg nikotinamid per dag (dose avhengig av kroppsstørrelse). Til sammen er 528 personer randomisert, hvorav 30 i Norge. Studien avsluttes i april 2003. Det er uklart hva slags mekanisme som ligger til grunn for en eventuell forebyggende effekt av nikotinamid, men flere plausible muligheter er foreslått, blant annet beskyttelse av $\square$-cellene mot frie radikaler (73). Det er viktig å understreke at man bruker store doser og at det foreløpig ikke er påvist noen sikker effekt av nikotinamid. Det er uklart om eventuelle positive resultater kan generaliseres til den generelle befolkningen.

\section{Case-control studie i Norge}

Vi har samlet inn spørreskjemaer og biologisk prøvemateriale for DNA ekstraksjon og HLA-typing i en populasjonsbasert case-control studie i Vest-Ader. Dette er en pilotstudie som er et samarbeid mellom Aker diabetes forskningssenter, Folkehelsa og VestAgder Sentralsykehus. Alle nye tilfeller av type 1 diabetes i Vest-Agder 1989-1998 samt et stort antall 
kontroller tilfeldig trukket fra folkeregisteret har blitt invitert. 85 tilfeller (94\% av de inviterte) og 1071 kontroller ( $73 \%$ av de inviterte) har deltatt. I denne studien har vi undersøkt ulike forhold under svangerskapet, ammevaner, avvenningskost, bruk av vitamintilskudd og andre miljøfaktorer i barneårene. Hensikten er først å undersøke om det er assosiasjon mellom disse faktorene og risiko for type 1 diabetes, dernest å undersøke om det foreligger epidemiologisk interaksjon mellom bestemte miljøfaktorer og kjente HLA-risikoalleler. Analysene pågår i skrivende stund, så data kan foreløpig ikke presenteres. Det relativt lave antallet tilfeller i vår pilotstudie $i$ Vest-Agder gjør at vi ikke har statistisk styrke til å påvise svake effekter, mens middels sterke effekter (OR $\square 3$ ) kan påvises. Pilotstudien muliggjør planlegging av en større studie, ikke minst med tanke på presis formulering av hypoteser om interaksjon mellom HLA-type og miljøfaktorer. Spørsmålet om miljøfaktorer kan modifisere risikoen for type 1 diabetes også hos individer uten høyrisiko HLA-typer er viktig med tanke på potensialet for forebyggende intervensjoner.

\section{ER DET GRUNNLAG FOR Å STARTE INTER- VENSJONSSTUDIER?}

Spørsmålet om man skal sette i gang intervensjonsstudier for å forebygge type 1 diabetes må bedømmes ut fra en rekke kriterier, blant annet vitenskapelige, etiske, praktiske og økonomiske hensyn, både på individnivå og på populasjonsnivå. Vitenskapelige holdepunkter for å sette i gang en intervensjonsstudie kommer som regel fra epidemiologiske studier og/eller eksperimentelle studier i dyr eller in vitroforsøk. En finsk gruppe har som sagt satt $i$ gang en pilot intervensjonsstudie, men enkelte har hevdet at grunnlaget for å tro at det er en sammenheng mellom kumelk og diabetes er så svakt at man ikke burde sette i gang kontrollerte forsøk med unngåelse av intakte kumelkproteiner i spedbarnsperioden (19). Kritikken har først og fremst vært at det i case-control studier er mulighet for forskjellige typer bias, og en rekke invendinger har vært fremsatt mot den såkalte BSA-hypotesen $(19,36)$. Variasjonen i resultater mellom case-control studier kan være tilfeldig, og selv om BSA-hypotesen tilbakevises kan vi ikke utelukke at andre mekanismer er involvert. Andre mer generelle invendinger mot kumelkhypotesen er at insidensen av type 1 diabetes har steget $i$ Finland på tross av en vedvarende høy prevalens av amming, og at kumelk ikke kan være årsaken til at insidensen øker i Finland i dag fordi man har drukket kumelk i lange tider. Dette er riktig, men siden type 1 diabetes er en multifaktoriell sykdom utelukker ikke dette muligheten for at en sammenheng kan eksistere på individnivå. Enkelte har også fremholdt som kritikk mot kumelkhypotesen muligheten for at kostholdet kan ha betydning også senere i livet (19). Dette er foreløpig spekulasjoner, og vi mener at uavhengig om kostholdet spiller en eventuell rolle senere i livet er det interessant å vite om intervensjon tidlig i livet kan ha effekt. Når en rekke typer indirekte evidens støtter at det kan være en sammenheng er det kanskje grunnlag for å starte intervensjonsstudier. På den annen side burde man kanskje først gjennomføre en vel-designet prospektiv observasjonsstudie, på tross av at det ville være forbundet med store kostnader. I en planlagt substudie i Den norske mor-barn undersøkelsen skal barn med høyrisiko HLA-typer følges opp med tanke på diabetesassosierte autoantistoffer og type 1 diabetes. Her skal man prospektivt registrere amme- og matvaner hos barna, i tillegg til en rekke andre eksponeringsfaktorer.

Når det gjelder andre kostfaktorer enn kumelk/ amming er det bestemt ikke grunnlag for anbefalinger om å endre kostholdet for å forebygge type 1 diabetes, og det er foreløpig neppe grunnlag for å starte intervensjonsstudier (med unntak for nikotinamid). Det er imidlertid flere interessante hypoteser som bør følges opp.

Vi er optimistiske med tanke på å kunne forebygge type 1 diabetes i framtiden, men foreløpig ser det ut til at tiltak kun vil være aktuelle for personer med økt risiko for å utvikle sykdom. Av ulike grunner er deltakerne i randomiserte kontrollerte studier personer med øt risiko for å utvikle type 1 diabetes (har slektninger med diabetes, høyrisiko HLA-typer og/eller prediabetes). Kunnskapen vi vil få fra disse studiene er ikke nødvendigvis generaliserbar til andre grupper i befolkningen. For å identifisere disse høyrisikoindividene kreves screening av et stort antall mennesker på grunnlag av familiehistorie, genetiske markører, diabetesassosierte autoantistoffer, eller en kombinasjon av disse. Av alle personer med type 1 diabetes har omkring $10 \%$ en eller flere førstegradsslektninger som også har sykdommen. Med screening på grunnlag av familiehistorie vil man altså kunne identifisere langt under $10 \%$ av fremtidige tilfeller, og potensialet for drastisk reduksjon av populasjonsinsidensen er ikke til stede selv med meget effektiv intervensjon.

Mye forskning er rettet mot å øke evnen til å kunne predikere type 1 diabetes (30). Med en omfattende screeningprosess basert på flere av kriteriene nevnt over kan man i dag identifisere individer som har inntil $70-80 \%$ sjanse for å få type 1 diabetes innen de neste 5-10 årene. Foreløpig har ingen studier fulgt personer lengre enn 5-10 år, og de fleste studiene er gjort blant førstegradsslektninger til personer med type 1 diabetes. Denne screeningen er forbundet med relativt store kostnader, og vil ikke kunne identifisere alle som vil få diabetes. Allikevel er type 1 diabetes forbundet med så store kostnader på mange nivåer, både for individer og for samfunnet, at det kan tenkes at kostbare intervensjoner er noe å satse på. Forskere ved Seksjon for epidemiologi ved Folkehelsa har satt i gang en studie for å estimere kostnader og nytte som potensielt kan være forbundet med intervensjoner rettet mot type 1 diabetes, gitt at vi har en effektiv forebyggende behandling. Resultater fra pågående randomiserte studier for å 
forebygge type 1 diabetes (nikotinamid, unngåelse av kumelk tidlig i livet og andre) vil forhåpentligvis bringe oss et skritt videre i spørsmålet om sykdommen kan forebygges, men det vil ta flere år før vi vet om forebyggingen er vedvarende.

\section{KONKLUSJON}

Etiologien til type 1 diabetes er multifaktoriell, med flere gener og flere miljøfaktorer involvert. Vi har et godt teoretisk grunnlag for å anta at kostholdsfaktorer kan spille en rolle i utviklingen av type 1 diabetes, og en rekke mer eller mindre plausible hypoteser er foreslått $(23,74)$. Mye data støtter at en sammenheng eksisterer, men for å akseptere at det er en kausal sammenheng, og at det er grunnlag for å sette igang forebyggende intervensjoner må vi stille strenge metodiske krav. Av de potensielle faktorer som hittil har vært foreslått, er tidlig introduksjon av kumelk og/eller kortvarig amming de som er mest lovende med tanke på forebyggende tiltak. Det er imidlertid etter vårt syn foreløpig ikke grunnlag for å gå ut med anbefalinger om å endre kostvaner for å forebygge type 1 diabetes, verken i familier med diabetes eller for andre. På en annen side er det gode grunner til å drive mer forsking på sammenhengen mellom kostholdsfaktorer og type 1 diabetes, ettersom potenisalet for forebygging er til stede hvis sammenhengen viser seg å være kausal.

\section{REFERANSER}

1. Atkinson MA, Maclaren NK. The pathogenesis of insulin-dependent diabetes mellitus. N Engl J Med 1994; 24: 1428-36.

2. Gorsuch AN, Spencer KM, Lister J, McNally JM, Dean BM, Bottazzo GF, Cudworth AG. Evidence for a long prediabetic period in type 1 (insulin dependent) diabetes mellitus. Lancet 1981; 2: 1363-5.

3. Joner G, Søvik O. Increasing incidence of diabetes mellitus in Norwegian children 0-14 years of age 19731982. Diabetologia 1989; 32: 79-83.

4. Green A. Recent trends in the epidemiology of type 1 diabetes. Diabetes Annual 1996; 10: 51-64.

5. Mølbak AG, Christau B, Marner B, Borch-Johnsen K, Nerup J. Incidence of insulin-dependent diabetes mellitus in age groups over 30 years in Denmark. Diabetic Med 1994; 11: 650-5.

6. Karvonen M, Tuomilehto J, Libman I, LaPorte R. A review of the recent epidemiological data on the worldwide incidence of type 1 (insulin-dependent) diabetes mellitus. World Health Organization DIAMOND Project Group. Diabetologia 1993; 36: 883-92.

7. Thorsby E, Rønningen KS. Particular HLA-DQ molecules play a dominant role in determining susceptibility or resistance to type 1 (insulin-dependent) diabetes mellitus. Diabetologia 1993; 36: 371-7.

8. Friday RP, Trucco M, Pietropaolo M. Genetics of type 1 diabetes mellitus. Diabetes Nutr Metab 1999; 12: 326.

9. Olmos P, A'Hern R, Heaton DA, Millward BA, Risley D, Pyke DA, Leslie RDG. The significance of the concordance rate for type 1 (insulin-dependent) diabetes in identical twins. Diabetologia 1988; 31: 747-50.

10. Kyvik KO, Green A, Beck-Nielsen H. Concordance rates of insulin dependent diabetes mellitus: a population based study of young Danish twins. BMJ 1995; 311: 913-7.

11. Onkamo P, Väänänen S, Karvonen M, Tuomilehto J. Worldwide increase in incidence of type 1 diabetes - the analysis of the data on published incidence trends. Diabetologia 1999; 42: 1395-403.

12. Nerup J, Mandrup-Poulsen T, Helqvist S, Andersen HU, Pociot F, Reimers JI, et al. On the pathogenesis of IDDM. Diabetologia 1994; 37 (suppl 2): S82-S89

13. Borch-Johnsen K, Joner G, Mandrup-Poulsen T, Christy M, Zachau-Christiansen B, Kastrup K, Nerup J. Relation between breast-feeding and incidence rates of insulin-dependent diabetes mellitus: a hypothesis. Lancet 1984; 2: 1083-6.

14. Elliott RB, Martin JM. Dietary protein: a trigger of insulin-dependent diabetes in the BB rat? Diabetologia 1984; 26: 297-9.

15. Drash AL, Kramer MS, Swanson J, Udall JN Jr. Infant feeding practices and their possible relationship to the etiology of diabetes mellitus. American Academy of Pediatrics Work Group on Cow's Milk Protein and Diabetes Mellitus. Pediatrics 1994; 94: 752-4.

16. Scott FW. AAP recommendations on cow milk, soy, and early infant feeding. Pediatrics 1995; 96: 515-7.

17. Elliott RB. Cow's milk and the diabetes debate. Pediatrics 1995; 96: 541.

18. MacLean WCJ. Cow's milk and the diabetes debate. Pediatrics 1995; 96: 541-2.

19. Ellis TM, Atkinson MA. Early infant diets and insulin-dependent diabetes. Lancet 1996; 347: 1464-5.

20. Scott FW. Cow milk and insulin-dependent diabetes mellitus: is the re a relationship? Am J Clin Nutr 1990; 51: 489-91. 
21. Dahl-Jørgensen K, Joner G, Hanssen KF. Relationship between cows' milk consumption and incidence of IDDM in childhood. Diabetes Care 1991; 14: 1081-3.

22. Fava D, Leslie RD, Pozzilli P. Relationship between dairy product consumption and incidence of IDDM in childhood in Italy. Diabetes Care 1994; 17: 1488-90.

23. Åkerblom HK, Knip M. Putative environmental factors in Type 1 diabetes. Diabetes Metab Rev 1998; 14: 3167.

24. Norris JM, Scott FW. A meta-analysis of infant diet and insulin-dependent diabetes mellitus: do bias play a role? Epidemiology 1996; 7: 87-92.

25. Kyvik KO, Green A, Svendsen A, Mortensen K. Breast feeding and the development of type 1 diabetes mellitus. Diabetic Med 1991; 9: 233-5.

26. Samuelsson U, Johansson C, Ludvigsson J. Breast-feeding seems to play a marginal role in the prevention of insulin-dependent diabetes mellitus. Diabetes Res Clin Pract 1993; 19: 203-10.

27. Patterson CC, Carson DJ, Hadden DR, Waugh N, Cole SK. A case-control investigation of perinatal risk factors for childhood IDDM in northern Ireland and Scotland. Diabetes Care 1994; 17: 376-81.

28. Norris J, Beaty B, Klingensmith G, Yu L, Hoffman M, Chase HP, et al. Lack of association between early exposure to cow's milk protein and -cell autoimmunity. JAMA 1996; 276: 609-14.

29. Couper JJ, Steele C, Beresford S, Powell T, McCaul K, Pollard A, et al. Lack of association between duration of breast-feeding or introduction of cow's milk and development of islet autoimmunity. Diabetes 1999; 48: 2145-9.

30. Bingley PJ, Williams AJK, Gale EAM. Optimized autoantibody-based risk assessment in family members. Implications for future interventions trials. Diabetes Care 1999; 22: 1796-801.

31. Verge CF, Gianini R, Kawasaki E, Yu L, Pietropaolo M, Jackson RA, Chase HP, Eisenbarth GS. Prediction of type 1 diabetes in first-degree relatives using a combination of insulin, GAD, and ICA512bdc/IA-2 autoantibodies. Diabetes 1996; 45: 926-33.

32. Hanson LÅ, Ahlstedt S, Andersson B, Carlsson B, Fällström SP, Mellander L, et al. Protective factors in milk and the development of the immune system. Pediatrics 1985; 75 (suppl): 172-6.

33. Savilahti E, Åkerblom HK, Tainio VM, Koskimies S. Children with newly diagnosed insulin-dependent diabetes mellitus have increased levels of cow's milk antibodies. Diabetes Res 1988; 7: 137-40.

34. Dahlquist G, Savilahti E, Landin-Olsson M. An increased level of antibodies to beta-lactoglobulin is as a risk determinant for early onset Type 1 (insulin-dependent) diabetes mellitus independent of islet cell antibodies and early introduction of cow's milk. Diabetologia 1992; 35: 980-4.

35. Karjalainen J, Martin JM, Knip M, Ilonen J, Robinson BH, Savilahti E, Åkerblom H, Dosch H-M. A bovine albumin peptide as a possible trigger of insulin-dependent diabetes mellitus. $N$ Engl J Med 1992; 327: 302-7.

36. Atkinson MA, Ellis TM. Infants diets and insulin-dependent diabetes: evaluating the "cows' milk hypothesis" and a role for anti-bovine serum albumin immunity. J Am Coll Nutr 1997; 16: 334-40.

37. Atkinson M, Bowman MA, Kao K-J, Campbell L, Dush P, Shah SC, Simell O, Maclaren N. Lack of immune responsiveness to bovine serum albumin in insulin-dependent diabetes. $N$ Engl J Med 1993; 329: 1853-8.

38. Rønningen KS, Atrazhev A, Luo L, Smith DK, Korbutt G, Rajotte RV, Elliott JF. Anti-BSA antibodies do not cross-react with the 69-kDa islet cell autoantigen ICA69. J Autoimmun 1998; 11: 223-31.

39. Cavallo MG, Fava D, Monetini L, Barone F, Pozzilli P. Cell-mediated immune response to beta casein in recent-onset insulin-dependent diabetes: implications for disease pathogenesis. Lancet 1996; 348: 926-8.

40. Elliott RB, Harris DP, Hill JP, Bibby NJ, Wasmuth HE. Type 1 (insulin-dependent) diabetes mellitus and cow milk: casein variant consumption. Diabetologia 1999; 42: 292-6.

41. Vaarala O, Paronen J, Otonkoski T, Akerblom HK. Cow milk feeding induces antibodies to insulin in children - a link between cow milk and insulin-dependent diabetes mellitus? Scand J Immunol 1998; 47: 131-5.

42. Vaarala O, Knip M, Paronen J, Hamalainen AM, Muona P, Vaatainen M, et al. Cow's milk formula feeding induces primary immunization to insulin in infants at genetic risk for type 1 diabetes. Diabetes 1999; 48: 1389-94.

43. Harrison LC, Honeyman MC. Cow's milk and type 1 diabetes: the real debate is about mucosal immune function. Diabetes 1999; 48: 1501-7.

44. Åkerblom HK, Savilahti E, Saukkonen T, Peganus A, Virtanen SM, Teramo K, et al. The case for elimination of cow's milk in early infancy in the prevention of type 1 diabetes: The Finnish experience. Diabetes Metab Rev 1993; 9: 269-78.

45. Catassi C, Guerrieri A, Bartolotta E, Coppa GV, Giorgi PL. Antigliadin antibodies at onset of diabetes in children. Lancet 1987; 2: 158.

46. Cronin CC, Shanahan F. Insulin-dependent diabetes mellitus and coeliac disease. Lancet 1997; 349: $1096-7$.

47. Saukkonen T, Savilahti E, Reijonen H, Ilonen J, Tuomilehto-Wolf E, Akerblom HK. Coeliac disease: frequent occurrence after clinical onset of insulin-dependent diabetes mellitus. Childhood Diabetes in Finland Study Group. Diabetic Med 1996; 13: 464-70. 
48. Sollid LM, Markussen G, Ek J, Gjerde H, Vartdal F, Thorsby E. Evidence for a primary association of celiac disease to a particular HLA-DQ alpha/beta heterodimer. $J$ Exp Med 1989; 169: 345-50.

49. Bao F, Yu L, Babu S, Wang T, Hoffenberg EJ, Rewers M, Eisenbarth GS. One third of HLA DQ2 homozygous patients with type 1 diabetes express celiac disease-associated transglutaminase autoantibodies. $J$ Autoimmun 1999; 13: 143-8.

50. Lie BA, Sollid LM, Ascher H, Ek J, Akselsen HE, Ronningen KS, Thorsby E, Undlien DE. A gene telomeric of the HLA class I region is involved in predisposition to both type 1 diabetes and coeliac disease. Tissue Antigens 1999; 54: 162-8.

51. Hoorfar J, Buschard K, Dagnaes-Hansen F. Prophylactic nutritional modification of the incidence of diabetes in autoimmune non-obese diabetic (NOD) mice. Br J Nutr 1993; 69: 597-607.

52. Scott FW, Cloutier HE, Kleemann R, Woerz-Pagenstert U, Rowsell P, Modler HW, Kolb H. Potential mechanisms by which certain foods promote or inhibit the development of spontaneous diabetes in BB rats. Diabetes 1997; 46: 589-98.

53. Kostraba J, Cruickshanks KJ, Lawler-Heavner J, Jobim LF, Rewers M, Gay EC, et al. Early exposure to cow's milk and solid foods in infancy, genetic predisposistion, and risk of IDDM. Diabetes 1993; 42: 288-95.

54. Fort P, Lanes R, Dahlem S, Recker B, Weyman-Daum M, Pugliese M, Lifshitz F. Breast feeding and insulindependent diabetes mellitus in children. J Am Coll Nutr 1986; 5: 439-41.

55. Klemetti P, Savilahti E, Ilonen J, Akerblom HK, Vaarala O. T-cell reactivity to wheat gluten in patients with insulin-dependent diabetes mellitus. Scand J Immunol 1998; 47: 48-53.

56. Helgason T, Jonasson MR. Evidence for a food additive as a cause of ketosis-prone diabetes. Lancet 1981; 2: 716-20.

57. Like AA, Rossini AA. Streptozotocin-induced pancreatic insulitis: new model of diabetes mellitus. Science 1976; 193: 415-7.

58. Helgason T, Ewen SW, Ross IS, Stowers JM. Diabetes produced in mice by smoked/cured mutton. Lancet 1982; 2: 1017-22.

59. Kostraba J, Gay E, Rewers M, Hamman R. Nitrate levels in community drinking waters and risk of IDDM. Diabetes Care 1992; 15: 1505-8.

60. Parslow RC, McKinney PA, Law GR, Staines A, Williams R, Bodansky HJ. Incidence of childhood diabetes mellitus in Yorkshire, northern England, is associated with nitrate in drinking water: an ecological analysis. Diabetologia 1997; 40: 550-6.

61. Van Maanen JMS, Albering HJ, Van Breda SGJ, Curfs DMJ, Ambergen AW, Wolffenbuttel BHR, Kleinjans JCS, Reeser HM. Nitrate in drinking water and risk of childhood diabetes in the Netherlands (letter). Diabetes Care 1999; 22: 1750.

62. Siemiatycki J, Colle E, Campbell S, Dewar RAD, Belmonte MM. Case-control study of IDDM. Diabetes Care 1989; 12: 209-16.

63. Dahlquist G, Blom LG, Persson LÅ, Sandstrøm A, Wall S. Dietary factors and the risk of developing insulin dependent diabetes in childhood. BMJ 1990; 300: 1302-6.

64. Verge CF, Joward NJ, Irwig L, Simpson JM, Mackerras D, Silink M. Environmental factors in childhood IDDM. Diabetes Care 1994; 17: 1381-9.

65. Virtanen SM, Jaakkola L, Rasanen L, Ylonen K, Lounamaa R, Åkerblom HK, Tuomeilehto J. Nitrate and nitrite intake and the risk for type 1 diabetes in Finnish Children. Diabetic Med 1994; 11: 656-62.

66. Mauricio D, Mandrup-Poulsen T, Nerup J. Vitamin D analogues in insulin-dependent diabetes mellitus and other autoimmune diseases: a therapeutic perspective. Diabetes Metab Rev 1996; 12: 57-68.

67. EURODIAB Substudy 2 Study Group. Vitamin D supplement in early childhood and risk for type 1 (insulindependent) diabetes mellitus. Diabetologia 1999; 42: 51-4.

68. Himsworth HP. Diet and the incidence of diabetes mellitus. Clin Sci 1935; 2: 117-48.

69. Pozzilli P, Bottazzo GF. Coffee or sugar: which is to blame in IDDM (letter). Diabetes Care 1991; 14: 144-5.

70. Elliott RB, Chase P. Prevention or delay of Type 1 (insulin-dependent) diabetes mellitus in children using nicotinamide. Diabetologia 1991; 34: 362-5.

71. Swendseid ME, Jocob RA. Niacin. In: Shils ME, Olson JA, Shike M, editors. Modern nutrition in health and disease, 8th edn. Philadelphia: Lea \& Febiger, 1994, p. 376.

72. National Research Council. Recommended dietary allowances, 10th edn. Washington D.C.: National Academy Press, 1989, p. 137.

73. Mandrup-Poulsen T, Reimers JI, Andersen HU, Pociot F, Karlsen AE, Bjerre U, Nerup J. Nicotinamide treatment in the prevention of insulin-dependent diabetes mellitus. Diabetes Metab Rev 1993; 9: 295-309.

74. Scott FW, Elliott RB, Kolb H. Diet and autoimunity: Prospects of prevention of type 1 diabetes. Diabetes Metab Rev 1989; 2: 61-73. 